\title{
PENGGUNAAN PATI SAGU TERMODIFIKASI DENGAN HEAT MOISTURE TREATMENT SEBAGAI BAHAN SUBSTITUSI UNTUK PEMBUATAN MI KERING
}

\section{THE USE OF HEAT MOISTURE TREATMENT-MODIFIED SAGO STARCH AS A SUBSTITUTE INGREDIENT FOR DRIED NOODLE PRODUCT}

\author{
Judith Henny Mandei \\ Balai Riset dan Standardisasi Industri Manado \\ Jalan Diponegoro No. 21-23 Manado \\ e-mail: nenimandei@yahoo.com \\ Diterima 27-05-2016, Disetujui tgl 01-06-2016
}

\begin{abstract}
ABSTRAK
Penelitian penggunaan pati sagu termodifikasi sebagai bahan substitusi untuk pembuatan mi telah dilaksanakan. Tujuan penelitian adalah untuk memperoleh pati sagu termodifikasi HMT dengan karakteristik yang sesuai untuk diaplikasikan pada pembuatan produk mi kering, serta mendapatkan formula (perbandingan pati sagu termodifikasi dan tepung terigu) yang dapat menghasilkan mi yang memenuhi syarat mutu mi kering. Penelitian terdiri atas beberapa tahapan yaitu karakterisasi pati sagu alami, modifikasi pati sagu dengan teknik heat moisture treatment (HMT), dan aplikasi pati sagu termodifikasi HMT sebagai substitusi pada pembuatan mi. Perlakuan yang dicobakan adalah substitusi pati sagu termodifikasi HMT 0\%, 10\%, 20\%, 30\%, 40\%, 50\%, 60\%, 70\%, 80\%, 90\%, 100\% dan sebagai pembanding digunakan substitusi pati sagu alami $50 \%$. Pati sagu alami diuji kadar air, kadar abu, serat kasar, kadar pati, fraksi amilosa dan amilopektin, swelling power dan kelarutan. Pati sagu termodifikasi HMT diuji kadar air, kadar pati, fraksi amilosa dan amilopektin, swelling power dan kelarutan. Produk mi kering diuji kadar air, kadar protein, kadar abu tidak larut dalam asam, keadaaan mi (bau, rasa, warna dan tekstur) sesuai SNI 8217:2015 syarat mutu mi kering, dan sifat fungsional mi diukur waktu optimum rehidrasi, cooking loss, dan daya serap air. Hasil penelitian menunjukkan bahwa pati sagu alami memiliki kadar air 7,48\%, kadar abu 0,062\%, serat kasar 0,04\%, dan kadar pati $88,31 \%$, semuanya memenuhi syarat mutu tepung sagu SNI 3729:2008, dengan kandungan fraksi amilosa 20,00\%, fraksi amilopektin $39,50 \%$, swelling power 4,35 (gr/gr) dan kelarutan 6,06\%. Hasil modifikasi pati sagu secara HMT merubah sifat fungsional pati sagu yaitu meningkatkan kandungan fraksi amilosa menjadi $25,00 \%$, kelarutan pati sagu menjadi $17,2 \%$ dan sedikit menurunkan swelling power dari pati sagu menjadi 3,63 (gr/gr). Pati sagu termodifikasi HMT dapat dimanfaatkan sebagai bahan substitusi tepung terigu dalam pembuatan mi kering, juga sebagai bahan baku baku pengganti tepung terigu. Mi kering menggunakan 100\% pati sagu termodifikasi HMT memiliki waktu optimum rehidrasi 7,5 menit yang relatif lebih lama dari waktu optimum rehidrasi mi kering pada umumnya yaitu sekitar 4 menit, juga memerlukan waktu yang lebih lama dalam pembentukan adonan untuk menghasilkan adonan yang cukup khalis dan tidak mudah patah. Dibandingkan dengan SNI 8217:2015 syarat mutu mi kering (berbahan baku tepung terigu), mi kering yang dibuat dengan substitusi pati sagu termodifikasi HMT sampai 30\% memenuhi syarat mutu.
\end{abstract}

Kata kunci: Pati sagu termodifikasi HMT, mi kering

\section{ABSTRACT}

This study examined the use of modified sago starch as a substitute ingredient for dried noodle product. Research objectives are to obtain the most suitable characteristic of Heat Moisture Treatment sago starch in dried noodle production, and to find the best combination of wheat flour and HMT-modified sago starch composition which complies with dried noodle requirement standard. This study applied several phases, namely characterising natural sago starch; modifying sago starch using heat moisture treatment; and applying HMT-modified sago starch as a substitute ingredient in dried noodle production. Treatments were tested by substituting HMT-modified sago starch of $0 \%, 10 \%, 20 \%, 30 \%, 40 \%, 50 \%, 60$, $70 \%, 80 \%, 90 \%, 100 \%$ substitution levels, and compared to $50 \%$ of natural sago starch. The natural sago starch was examined for its water content, ash content, crude fiber, starch content, amylase and amylopectin fraction, swelling power and solubility. Following that, the dried noodles were observed for its water content, protein content, acid-insoluble ash, noodle appearance (smell, taste, colour, and texture) in compliance with the National Standard No. 8217:2015 of dried noodle requirement. The functional properties of noodle were measured by optimum rehydration time, cooking loss, and water absorption. This research shows that natural sago starch has $7.48 \%$ water content; $0.062 \%$ ash content; $0.04 \%$ crude fiber; 88.31\% starch content (which all comply with the Indonesian Standard No. 8217:2015 of dried noodle standard requirement), with the content of amylase fraction $20.00 \%$, amylopectin fraction $39.50 \%$, swelling power 4.35 (gr/gr), and solubility of $6.06 \%$. The result of HMT-modified sago starch indicates that 
it changes the functional properties of sago starch by increasing amylase fraction to $25.00 \%$, solubility to $17.2 \%$, but it reduces swelling power to 3.63 (gr/gr). The HMT-modified sago starch not only can be used as a substitute for wheat flour in the dried noodle production, but also as an alternative ingredient for wheat flour material. The dried noodle made from 100\% of HMT-modified sago starch has an optimum rehydration time of 7.5 minutes which is relatively longer compared to the common dried noodle 4 minutes. And also it took a longer time to make smooth and elastic dough.In compliance to the National Standard no. 8217:2015 of dried noodle (from wheat flour), the proportion of HMT-modified sago starch from 0 to $30 \%$ fulfils the quality requirements.

Keywords: HMT- modified sago starch, dry noodle

\section{PENDAHULUAN}

Sagu merupakan tanaman pangan asli Indonesia (pangan lokal) yang jumlah komoditasnya cukup besar. Tanaman sagu merupakan penghasil pati tertinggi di antara komoditas komersial penghasil pati. Walaupun dalam berbagai hasil penelitian dilaporkan bahwa potensi hasil pati sagu dapat mencapai 25 ton/ha, tetapi produksi rata-rata tanaman sagu tradisional hanya sekitar 10 ton/ha/tahun [1].

Dalam perdagangan dikenal dua macam pati yaitu pati yang belum dimodifikasi (pati alami) dan pati yang telah dimodifikasi. Pati alami mempunyai beberapa kendala jika dipakai sebagai bahan baku dalam industri pangan maupun non pangan. Jika dimasak pati membutuhkan waktu yang lama (hingga butuh energi tinggi), juga pasta yang terbentuk keras dan tidak bening. Disamping itu sifatnya terlalu lengket dan tidak tahan perlakuan dengan asam. Kendala-kendala tersebut menyebabkan pati alami terbatas penggunaannya dalam industri [2]. Seiring perkembangan teknologi di bidang pengolahan pati, maka pati alami dapat dimodifikasi/dilakukan perubahan struktur guna meningkatkan sifat-sifat spesifik dan memperluas penggunaannya dalam produk pangan. Modifikasi dapat dilakukan secara fisik, kimia maupun enzimatik. Pati alami dapat dibuat menjadi pati termodifikasi dengan sifat sifat yang dikehendaki atau sesuai dengan kebutuhan [3]. Beberapa penelitian tentang pati termodifikasi dari pati sagu telah dilakukan untuk melihat karakteristik dari pati yang telah dimodifikasi baik secara fisik dengan perlakuan Heat Moisture Treatment $[4,5,6]$, dan secara kimia dengan metode asetilasi dan cross-linking [7]. Sedangkan tinjauan sifat dan karakteristik pati sagu alami dan pati sagu termodifikasi telah dilakukan $[8,9]$, dimana setiap metode modifikasi dapat menghasilkan pati termodifikasi dengan sifat yang berbedabeda.

Pati sagu alami mengandung amilosa $27 \%$ dan amilopektin $73 \%$. Kandungan amilopektin yang tinggi memberikan sifat lengket sehingga kurang cocok untuk diaplikasikan pada produkproduk seperti cake, roti dan mi. Oleh karena itu untuk dapat digunakan sebagai bahan dalam pembuatan mi maka struktur pati sagu perlu dimodifikasi untuk memperbaiki sifat-sifat dari pati sagu.

Produk mi dibuat dari tepung terigu yang sampai saat ini masih diimpor baik dalam bentuk tepung maupun dalam bentuk biji gandum. Untuk mengurangi ketergantungan terhadap terigu maka dikembangkan produk mi dengan bahan substitusi pati sagu termodifikasi. Dalam 
penelitian ini pati sagu akan dimodifikasi secara fisik dengan metode Heat Moisture Treatment atau perlakuan kombinasi suhu dan moisture. Modifikasi pati sagu dengan teknik HMT dapat mengubah profil pasta pati menjadi lebih stabil dan sesuai untuk pembuatan mi [10]. Adapan tujuan penelitian ini adalah untuk memperoleh pati sagu termodifikasi HMT dengan karakteristik yang sesuai untuk diaplikasikan pada pembuatan produk mi kering, serta mendapatkan formula (perbandingan pati sagu termodifikasi dan tepung terigu) yang dapat menghasilkan mi yang memenuhi syarat mutu mi kering.

\section{BAHAN DAN METODE}

\section{Bahan dan Alat}

Bahan-bahan yang digunakandalam penelitian ini adalah tepung sagu baruk diperoleh dari pasar tradisional di Manado yangdidatangkan langsung dari Kabupaten Kepulauan Sangihe dikenal dengan nama sagu baruk (Arenga microcarpha, B.), tepung sagu termodifikasi, tepung terigu, telur, garam, soda abu/larutan alkali, dan air, serta bahan-bahan untuk analisis laboratorium.

Alat-alat yang digunakan terdiri dari timbangan, oven,loyang plastik bertutup, sendok, pengaduk, alat pencampur adonan, alat cetak mi, kompor, panci stainless steel, gelas ukur, dan peralatan untuk analisis laboratorium.

\section{Metode Penelitian}

Penelitian ini terdiri atas beberapa tahapan yaitu pertama karakterisasi pati sagu alami. Tahap kedua adalah modifikasi pati sagu, dilakukan dengan teknik heat moisture treatment (HMT). Tahap ketiga adalah aplikasi pati sagu termodifikasi sebagai substitusi tepung terigu pada pembuatan mi, dengan perlakuan:

- $0 \%$ pati sagu $\mathrm{HMT}+100 \%$ tepung terigu (HMT 0)

- $10 \%$ pati sagu HMT + $90 \%$ tepung terigu (HMT 10)

- $20 \%$ pati sagu HMT + $80 \%$ tepung terigu (HMT 20)

- $30 \%$ pati sagu HMT + $70 \%$ tepung terigu (HMT 30)

- $40 \%$ pati sagu HMT + $60 \%$ tepung terigu (HMT 40)

- $50 \%$ pati sagu $\mathrm{HMT}+50 \%$ tepung terigu (HMT 50)

- $60 \%$ pati sagu HMT + $40 \%$ tepung terigu (HMT 60)

- $70 \%$ pati sagu HMT + 30\% tepung terigu (HMT 70)

- $80 \%$ pati sagu $\mathrm{HMT}+20 \%$ tepung terigu (HMT 80)

- $90 \%$ pati sagu $\mathrm{HMT}+10 \%$ tepung terigu (HMT 90)

- $100 \%$ pati sagu HMT + $0 \%$ tepung terigu (HMT 100)

- $50 \%$ pati sagu alami $+50 \%$ tepung terigu

Setiap perlakuan diulang dua kali, dan setiap tahapan memiliki metode analisis yang berbeda.

\section{Prosedur Penelitian}

Penelitian tahap pertama: karakterisasi pati sagu alami.

Tepung sagu dicuci, dikeringkan, digiling dan diayak dengan ayakan 80 mesh. Sesudah itu diuji mutu tepung sagu meliputi 
kadar air, kadar pati, kadar abu, kadar serat kasarsesuai SNI 3729:2008 [11], fraksi amilosa dan amilopektin, swelling power dan kelarutan pati.

Penelitian tahap kedua: modifikasi pati sagu, dilakukan dengan teknik heat moisture treatment (HMT). Tepung sagu yang sudah diketahui kadar air awalnya diatur kembali kadar airnya sampai $28 \%$ dengan cara menyemprotkan aquades. Jumlah aquades yang disemprotkan ditentukan berdasarkan perhitungan kesetimbangan massa. Contoh perhitungan kesetimbangan massa adalah sebagai berikut:

$\left(100 \%-\mathrm{KA}_{1}\right) \times \mathrm{BP}_{1}=\left(100 \%-\mathrm{KA}_{2}\right) \times \mathrm{BP}_{2}$, dimana:

$\mathrm{KA}_{1}=$ Kadar air pati kondisi awal

$\mathrm{KA} 2=$ Kadar air pati yang diinginkan

$\mathrm{BP}_{1}=$ Bobot pati pada kondisi awal

$\mathrm{BP}_{2}=$ Bobot pati setelah mencapai $\mathrm{KA}_{2}$ Jumlah aquades $=$ BP2 - BP1

Pati basah yang telah mencapai kadar air $28 \%$ selanjutnya ditempatkan di dalam loyang bertutup kemudian diaduk. Pati didiamkan dalam refrigerator selama satu malam untuk penyeragaman kadar air. Pati basah dipanaskan dalam oven bersuhu $110^{\circ} \mathrm{C}$, selama 4 jam. Pati diaduk setiap 2 jam untuk menyeragamkan distribusipanas. Setelah didinginkan, pati termodifikasi dikeringkan selama 4 jampada suhu $50^{\circ} \mathrm{C}$. Pati sagu hasil perlakuan HMT diuji kadar air, kadar fraksi amilosa dan amilopektin, swelling power, dan kelarutan.

Penelitian tahap ketiga: Pembuatan mi dengan substitusi pati sagu hasil HMT.

Bahan baku pati sagu hasil HMT dan tepung terigu ditimbang sesuai perlakuan. Kemudian dicampur hingga homogen.
Proses selanjutnya dapat dilihat pada Gambar 1.

Mi yang diperoleh dilakukan pengujian mutu mi kering meliputi nilai gizi yaitu kadar air, protein dan kadar abu tidak larut dalam asam sesuai SNI 8217:2015 [12]; pengujian sifat fungsional mi yaitu waktu optimum rehidrasi (cooking time), kapasitas pengembangan (daya serap air) dan kehilangan padatan akibat pemasakan (cooking loss); pengujian organoleptik terhadap warna, bau, rasa dan tekstur mi.

\section{Prosedur Pengujian \\ Swelling Power dan Kelarutan}

Swelling power dan kelarutan ditentukan pada temperatur $70^{\circ} \mathrm{C}$ menurut Leach et al [13], dengan cara: $0.1 \mathrm{~g}$ sampel didispersikan dalam $9 \mathrm{ml}$ air dalam tabung sentrifus yang sudah diketahui beratnya. Tabung dipanaskan pada suhu $70^{\circ} \mathrm{C}$ selama 30 menit terus diaduk agar tidak mengendap. Pasta (yang terbentuk sebagai hasil gelatinisasi) disentrifus pada kecepatan $2250 \mathrm{rpm}$ selama 20 menit. Supernatan dipisahkan dari endapan yang terbentuk. 


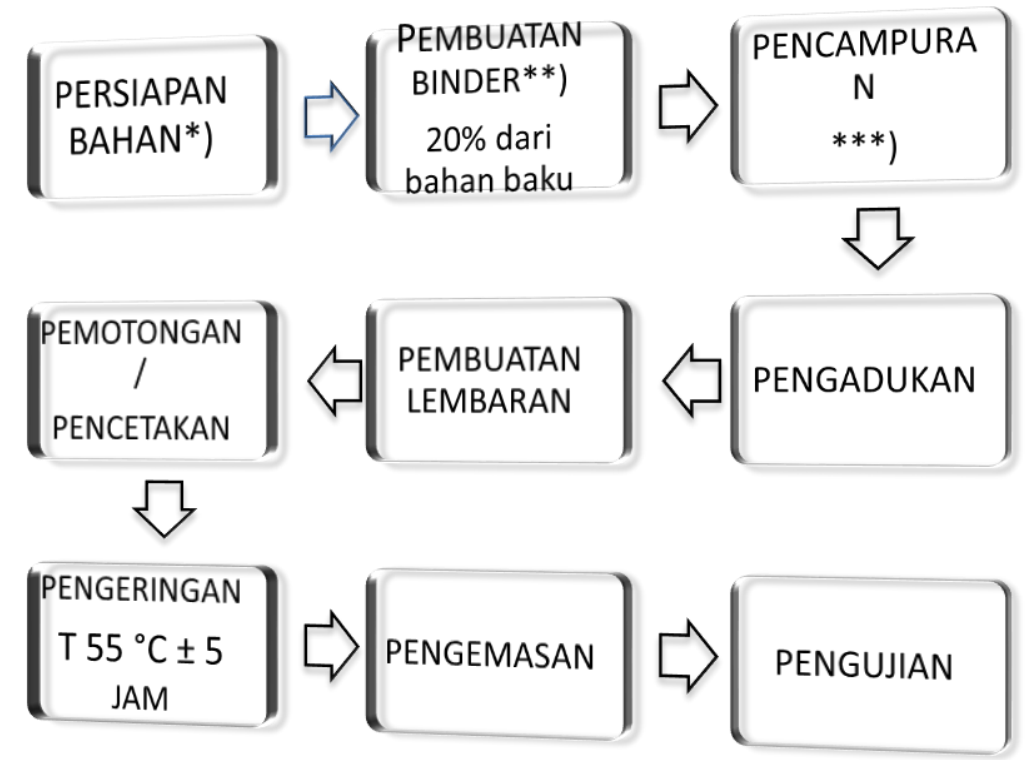

Ket.: *) $\quad$ Formula bahan yang digunakan: Bahan baku (pati sagu + tepung terigu, sesuai perlakuan) + bahan tambahan (telur 10\% + garam $0,5 \%$ + larutan soda $5{ }^{\circ}$ Baume, $8 \%$ + air $\pm 35 \%$ ), prosentase bahan tambahan dihitung per jumlah bahan baku (pati sagu + tepung terigu).

${ }^{* *}$ ) Dimasak/dibuat gel

${ }^{\star * *}$ Seluruh bahan tambahan dicampur ke binder, dan bahan baku ditambahkan sedikit demi sedikit sambil diaduk terus hingga terbentuk adonan yang khalis.

\section{Gambar 1. Diagram Proses Pembuatan Mi Kering.}

Supernatan dituang dalam cawan petri yang sudah diketahui bobotnya, diuapkan pada suhu $100^{\circ} \mathrm{C}$ selama $1-2$ jam dan ditimbang. Perbandingan berat supernatan kering dengan berat sampel pati kering adalah solubilitas (kelarutan) pati (\%). Endapan ditimbang dan selanjutnya swelling power diukur berdasarkan rasio perbandingan berat endapan terhadap berat sampel pati keringnya $(\mathrm{g} / \mathrm{g})$.

\section{Fraksi Amilosa dan Amilopektin}

Timbang pati sebanyak $0,1 \mathrm{gr}$ dan dilarutkan dalam $9 \mathrm{ml} \mathrm{HCl} \mathrm{0,1} \mathrm{N}$ dan 1,35 $\mathrm{ml}$ butanol.Panaskan larutan tersebut pada suhu $70{ }^{\circ} \mathrm{C}$ selama 30 menit.Dinginkan selama 2 jam pada suhu ruang.Setelah itu larutan tersebut disentrifugasi.Pisahkan endapan dan cairan sisa.Endapan dikeringkan kemudian ditimbang, untuk mendapatkan kandungan fraksi amilosa (\%). Timbang juga cairan sisa hasil sentrifugasi, kemudian ditambahkan $10 \mathrm{ml}$ metanol (terbentuk endapan putih). Saring dan timbang endapan yang ada di kertas saring (fraksi amilopektin).

\section{Waktu Optimum Rehidrasi [4]}

Timbang 5 gr mi sagu (dipotong sekitar 2-3 $\mathrm{cm}$, kemudian dimasak dalam $200 \mathrm{ml}$ air mendidih dengan wadah tertutup. Setiap 30 detik untaian dikeluarkan dan diamati dengan cara ditekan diantara dua buah alat kaca. Waktu optimum rehidrasi dicapai apabila bagian tengah mi sudah terhidrasi secara keseluruhan. 


\section{Kehilangan Padatan Akibat Pemasakan}

(\%) dan Kapasitas pengembangan (\%)[4] dimodifikasi

Pengujian dilakukan dengan menguapkan air rebusan mi hingga kering. Didihkan 40 $\mathrm{ml}$ air dalam gelas piala yang sudah diketahui beratnya. Masukkan $3 \mathrm{gr}$ mi dan dimasak selama 7,5 menit. Mi diangkat menggunakan saringan. Timbang mi yang sudah disaring. Air sisa rebusan diuapkan/dikeringkan dalam oven pada suhu $110^{\circ} \mathrm{C}$, dan ditimbang sampai berat tetap.

\section{Kehilangan padatan dihitung sebagai berikut:}

Berat padatan +gelas piala - berat gelas piala kosong $\times 100 \%$ Berat mi

\section{Kapasitas Pengembangan:}

Berat mi sesudah dimasak $\times 100 \%$ Berat mi sebelum dimasak

\section{Analisis Data}

Data yang diperolehdianalisisdan ditampilkan dalam bentuktabel dan gambar (histogram dan grafik).

\section{HASIL DAN PEMBAHASAN}

\section{Karakteristik Tepung Sagu Alami}

Tepung sagu yang diperoleh masih dalam keadaan semi basah sehingga perlu diperlakukan dengan pencucian, pengeringan, penggilingan dan pengayakan untuk mendapatkan tepung sagu yang berkualitas dan sesuai persyaratan.

Hasil pengujian karakteristik tepung sagu baruk dapat dilihat pada Tabel 3 .

Tabel 1. Hasil Pengujian Karakteristik Tepung Sagu Baruk

\begin{tabular}{|c|c|c|c|}
\hline No. & Parameter & Hasil Pengujian & $\begin{array}{c}\text { Persyaratan } \\
\left.\text { SNI } 3729: 2008^{\star}\right)\end{array}$ \\
\hline 1 & Kadar Air & $7,48 \%$ & Maks. $13 \%$ \\
\hline 2 & Kadar Abu & $0,062 \%$ & Maks. $0,5 \%$ \\
\hline 3 & Kadar Serat Kasar & $0,04 \%$ & Maks. $0,5 \%$ \\
\hline 4 & Kadar Pati & $88,31 \%$ & Min. $65 \%$ \\
\hline 5 & Fraksi Amilosa & $20,00 \%$ & - \\
\hline 6 & Fraksi Amilopektin & $39,50 \%$ & - \\
\hline 7 & Swelling Power**) & 4,35 (gr/gr) & - \\
\hline 8 & Kelarutan**) & $6,06 \%$ & - \\
\hline
\end{tabular}

Data pada Tabel 1 menunjukkan bahwa tepung sagu baruk yang siap dimodifikasi memenuhi syarat mutu tepung sagu (SNI $3729: 2008$ ), dengan fraksi amilosa 20,00\%, dan fraksi amilopektin 39,50\%. Tepung sagu baruk memiliki sifat swelling power1,58 (gr/gr), dan kelarutan 6,06\%. Sifat dan kualitas pati sagu dipengaruhi oleh faktor genetik maupun proses ekstraksinya [14]. Komposisi kimia pati sagu seperti dilaporkan dalam [15], yaitu kadar air 7,86-11,18\%, abu 0,06-0,43\%, serat kasar 3,69-5,96\% dan kandungan amilosa 20-33\%. Komposisi ini sedikit berbeda dengan tepung sagu baruk karena perbedaan jenis dan adanya treatment awal pada tepung sagu baruk yang digunakan dalam penelitian ini. Demikian juga dengan 
sifat fungsional tepung sagu baruk (swelling power dan kelarutan) yang dihasilkan yaitu 4,35 (gr/gr) dan $6,06 \%$, berbeda dengan sifat fungsional pati sagu yang dilaporkan dalam [9] yaitu swelling power10,14 (gr/gr) dan kelarutan $15,76 \%$.

\section{Pati Sagu TermodifikasiHeat Moisture Treatment (HMT)}

Pati sagu secara alami tidak memiliki sifat yang sesuai untuk tujuan tertentu sehingga dimodifikasi untuk mendapatkan sifat-sifat yang sesuai untuk penerapannya, dan untuk diterapkan dalam pembuatan mi maka dilakukan modifikasi pati sagu secara fisik yaitu Heat Moisture Treatment.

Hasil pengujian karakteristik pati sagu termodifikasi HMT dapat dilihat pada Tabel 4 berikut ini.

Tabel 2. Hasil Pengujian Karakteristik Pati Sagu Baruk Termodifikasi HMT

\begin{tabular}{clc}
\hline No. & Parameter & Hasil Pengujian \\
\hline 1 & Kadar Air & $16,13 \%$ \\
2 & Kadar Pati & $82,50 \%$ \\
3 & Fraksi Amilosa & $25,00 \%$ \\
4 & Fraksi Amilopektin & $36,55 \%$ \\
5 & Swelling Power $\left.^{\star}\right)$ & $3,63(\mathrm{gr} / \mathrm{gr})$ \\
6 & Kelarutan $\left.^{*}\right)$ & $17,2 \%$ \\
$\left.{ }^{*}\right)$ & pada Suhu $70^{\circ} \mathrm{C}$
\end{tabular}

Data pada Tabel 2 dibandingkan dengan Tabel 3 yaitu karakteristik pati sagu alami menunjukkan bahwa kadar amilosa dan kelarutan dari pati sagu termodifikasi mengalami peningkatan, sedangkan swelling power sedikit menurun. Modifikasi pati dengan teknik HMT dapat merusak bentuk granula pati hingga terbentuk lubang di bagian permukaannya. Proses pemanasan pati dan keberadaan air saat HMT berlangsung mengakibatkan area amosphous pati (amilosa) mengembang, kemudian menekan keluar area berkristal (amilopektin) sehingga terjadi kerusakan dan pelelehan area berkristal granula pati, serta menghasilkan bentuk granula pati yang lebih stabil terhadap panas [16]. Dengan rusaknya area berkristal (amilopektin) menyebabkan terjadinya kenaikan kadar amilosa. Semakin tinggi kandungan amilosa maka pembentukan gel semakin tidak mudah karena struktur amorf yang terbentuk dan memberikan sifat gel pati yang cenderung tidak lengket [17]. Sifat swelling dari pati sagu terutama disebabkan kandungan amilopektin, sedangkan aksi amilosa adalah sebagai penghambat (inhibitor) swelling, khususnya dengan adanya lipid ketika terbentuk kompleks amilosa-lipid [8]. Dalam Lay [18] dinyatakan bahwa sagu baruk memiliki kandungan lemak 1,40\%. Hal ini sesuai dengan hasil yang diperoleh dimana pati sagu modifikasi HMT swelling powemya menurun atau lebih rendah dari pati sagu alami, diduga berhubungan dengan meningkatnya kandungan amilosa yang dapat bertindak sebagai penghambat swelling. Efek yang dihasilkan dengan teknik modifikasi pati HMT antara lain yaitu peningkatan suhu 
gelatinisasi, pola difraksi sinar $\mathrm{X}$, peningkatan volume dan daya larut diikuti perubahan sifat fungsional lainnya [14].

\section{Karakteristik Mi Kering}

Karakteristik mi kering dengan substitusi pati sagu termodifikasi HMT yang diukur adalah mutu mi kering (kadar air, protein, kadar abu tidak larut dalam asam dan keadaan) dibandingkan dengan SNI 8217:2015 yaitu syarat mutu mi kering melalui proses produksi dikeringkan, dan sifat fungsional mi kering yaitu waktu optimum rehidrasi, kehilangan padatan akibat pemasakan (cooking loss) dan kapasitas pengembangan.

\section{Mutu Mi Kering}

Kadar Air Mi Kering

Hasil analisis kadar air mi kering dengan substitusi pati sagu dapat dilihat pada Gambar 2.

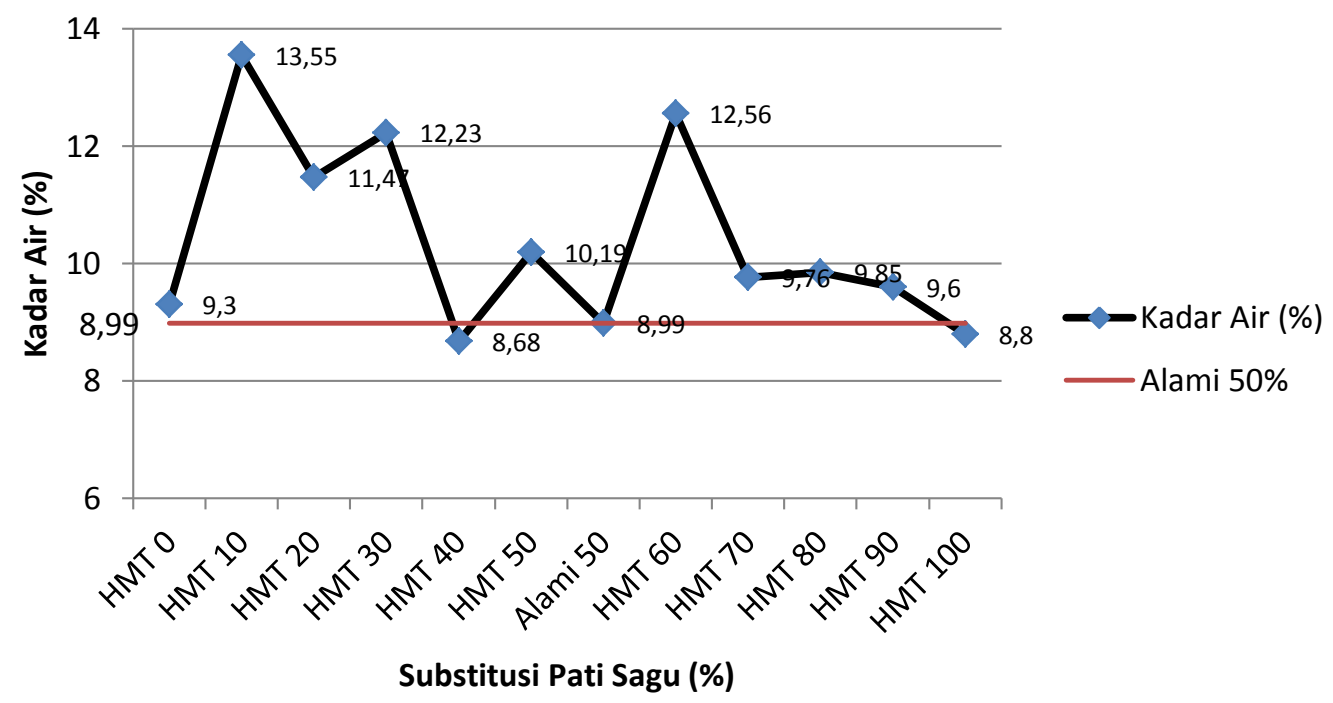

Gambar 2. Kadar Air Mi Kering dengan Perlakuan Substitusi Pati Sagu

Gambar 2 menunjukkan bahwa kadar air dari mi kering bervariasi dari 8,8 - 13,55\% dan tidak dipengaruhi oleh perlakuan substitusi pati sagu. Dibandingkan dengan SNI 8217:2015, kadar air mi kering memenuhi syarat mutu yaitu maksimal 13\%, kecuali perlakuan HMT 10\%.

\section{Kadar Protein Mi Kering}

Kadar protein mi kering dengan substitusi pati sagu termodifiksi HMT dapat dilihat pada Gambar 3. Gambar 3 menunjukkan bahwa semakin tinggi substitusi pati sagu termodifikasi semakin rendah kadar protein mi kering. Hal ini disebabkan kandungan protein dari pati sagu hanya sekitar $1,71 \%$
[18], sedangkan kandungan protein dari tepung terigu yang digunakan adalah $10 \%$. Sementara itu sebagai pembanding dibuat mi kering dengan substitusi $50 \%$ tepung sagu alami yang ternyata memiliki kadar protein $8,34 \%$ sedikit lebih tinggi dari $\mathrm{mi}$ kering dengan substitusi $50 \%$ pati sagu termodifikasi HMT dengan kadar protein $8,01 \%$. 


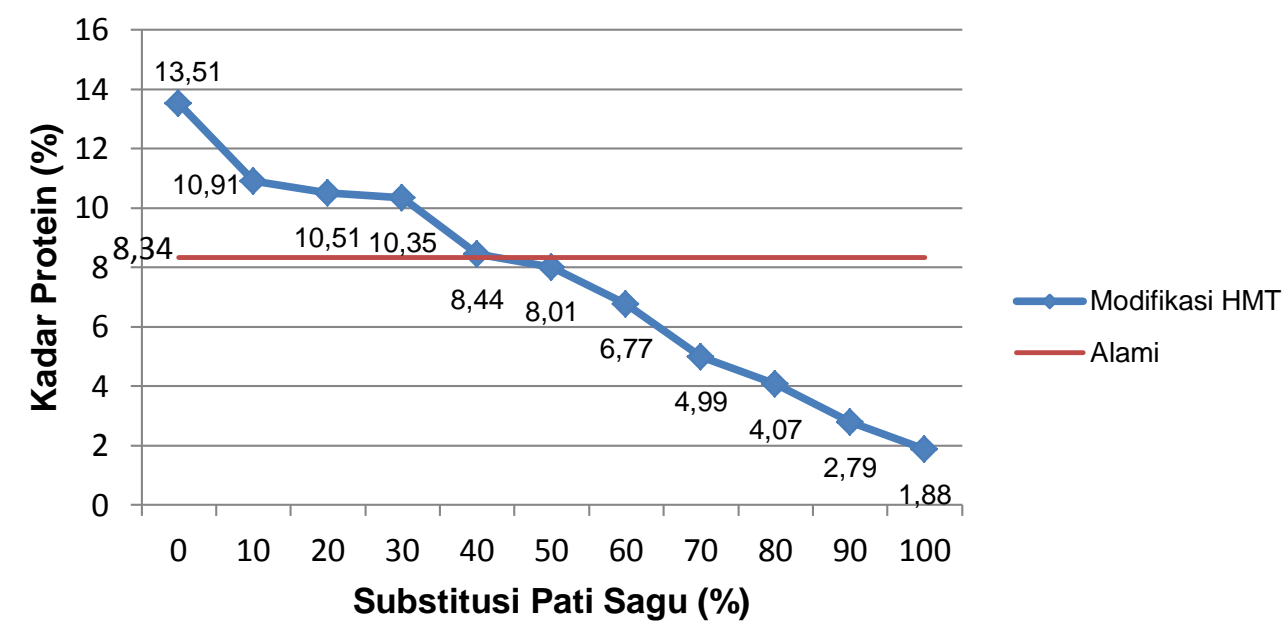

\section{Gambar 3. Kadar Protein Mi Kering dengan Perlakuan \\ Substitusi Pati Sagu}

Hal ini sesuai dengan hasil penelitian dari [19] yang menyatakan bahwa mi sagu kering dari pati sagu dengan perlakuan HMT akan terjadi penurunan kadar protein. Dibandingkan dengan persyaratan kadar protein mi kering berbahan baku tepung terigu melalui proses produksi dikeringkan (SNI 8217:2015) yaitu minimal 10\%, maka mi sagu dengan substitusi pati sagu termodifikasi HMT sampai $30 \%$ masih memenuhi syarat mutu.

\section{Kadar Abu tidak Larut dalam Asam Mi Kering}

Kadar abu yang larut dalam asam dimaksudkan untuk melarutkan kalsium karbonat, alkali klorida sedangkan yang tidak larut dalam asam biasanya mengandung silikat yang berasal dari tanah atau pasir. Adanya kandungan abu yang tidak larut dalam asam yang cukup tinggi menunjukkan adanya pasir atau kotoran lain [20].

Hasil pengujian kadar abu tidak larut dalam asam dari bebrapa contoh mi kering dapat dilihat pada Tabel 3.

Tabel 3. Hasil Analisis Kadar Abu Tidak Larut dalam Asam contoh Mi Kering

\begin{tabular}{ccc}
\hline No. & $\begin{array}{c}\text { Mi Kering dengan } \\
\text { Perlakuan }\end{array}$ & $\begin{array}{c}\text { Abu tidak larut dalam } \\
\text { Asam (\%) }\end{array}$ \\
\hline $\mathbf{1}$ & Tanpa Substitusi Pati & 0.03 \\
$\mathbf{2}$ & $\begin{array}{c}\text { Sagu HMT } \\
\text { Substitusi Pati Sagu } \\
\text { HMT 40\% }\end{array}$ & 0,07 \\
$\mathbf{3}$ & Pati Sagu HMT 100\% & 0,13 \\
\hline
\end{tabular}

Tabel 3 menunjukkan bahwa kadar abu tidak larut dalam asam mi kering dipengaruhi oleh bahan baku mi, dimana mi kering yang dibuat dari 100\% tepung terigu mengandung kadar abu tidak larut dalam asam yang sedikit $(0,03 \%)$, sedangkan $\mathrm{mi}$ kering dari pati sagu termodifikasi HMT $100 \%$ mengandung kadar abu tidak larut dalam asam yang sudah melebihi persyaratan SNI 8217:2015 yaitu maksimal 
$0,1 \%$. Hal ini mengindikasikan bahwa pati sagu termodifikasi HMT mengandung kotoran (pasir atau kotoran lain) yang tidak hilang pada proses pencucian.

\section{Keadaan Mi Kering}

Penilaian keadaan mi kering sesuai persyaratan SNI 8217:2015 meliputi bau, rasa, warna dan tekstur, dapat dilihat pada Tabel 4 berikut ini.

Tabel 4. Hasil Penilaian Organoleptik Keadaan dari Mi Kering

\begin{tabular}{|c|c|c|c|c|}
\hline $\begin{array}{c}\text { Substitusi } \\
\text { Pati Sagu } \\
(\%)\end{array}$ & Bau & Rasa & Warna & Tekstur \\
\hline HMT 0 & Normal & Normal & Putih gading & Normal/tidak mudah patah \\
\hline HMT 10 & Normal & Normal & Putih gading & Normal/tidak mudah patah \\
\hline HMT 20 & Normal & Normal & $\begin{array}{l}\text { Putih sedikit } \\
\text { kecoklatan }\end{array}$ & Normal/tidak mudah patah \\
\hline HMT 30 & Normal & Normal & $\begin{array}{l}\text { Putih sedikit } \\
\text { kecoklatan }\end{array}$ & Normal/tidak mudah patah \\
\hline HMT 40 & Normal & Normal & $\begin{array}{l}\text { Putih sedikit } \\
\text { kecoklatan }\end{array}$ & Normal/tidak mudah patah \\
\hline HMT 50 & Normal & Normal & $\begin{array}{l}\text { Putih sedikit } \\
\text { kecoklatan }\end{array}$ & Agak keras \\
\hline HMT 60 & Ada sedikit khas sagu & Normal & $\begin{array}{l}\text { kuning muda } \\
\text { kecoklatan }\end{array}$ & Agak keras \\
\hline HMT 70 & Ada sedikit khas sagu & Normal & $\begin{array}{l}\text { kuning muda } \\
\text { kecoklatan }\end{array}$ & Agak keras \\
\hline $\begin{array}{l}\text { HMT } 80 \\
\text { HMT } 90 \\
\text { HMT } 100\end{array}$ & $\begin{array}{l}\text { Ada sedikit khas sagu } \\
\text { Sedikit khas sagu } \\
\text { Khas sagu }\end{array}$ & $\begin{array}{l}\text { Normal } \\
\text { Normal } \\
\text { Normal }\end{array}$ & $\begin{array}{l}\text { kuning kecoklatan } \\
\text { kuning kecoklatan } \\
\text { coklat muda }\end{array}$ & $\begin{array}{l}\text { Agak keras } \\
\text { Agak keras } \\
\text { Agak lebih keras }\end{array}$ \\
\hline Alami 50 & Ada sedikit khas sagu & Normal & $\begin{array}{l}\text { Putih sedikit } \\
\text { kecoklatan }\end{array}$ & Agak lebih keras \\
\hline
\end{tabular}

Hasil penilaian terhadap keadaan mi kering (Tabel 4) menunjukkan bahwa untuk bau sampai dengan perlakuan substitusi pati sagu termodifikasi HMT 50\% masih tercium bau mi secara normal (bau khas pati dari adonan tepung terigu) atau bau khas sagu belum tercium. Bau khas pati sagu baru dapat terdeteksi melalui indera penciuman mulai perlakuan HMT 60. Penilaian terhadap rasa dari mi kering menghasilkan rasa yang normal/tidak terdeteksi adanya rasa yang menyimpang dari mi kering pada semua perlakuan yang dicobakan.

Hasil penilaian warna dari mi kering menunjukkan bahwa semakin banyak substitusi pati sagu termodifikasi HMT, warna mi kering yang dihasilkan semakin kecoklatan.
Hasil penilaian tekstur dari mi kering menunjukkan bahwa semakin banyak substitusi pati sagu termodifikasi HMT semakin keras tekstur mi kering yang dihasilkan. Dalam proses pembuatan mi kering, semakin banyak substitusi pati sagu termodifikasi HMT, semakin sulit dalam membentuk adonan mi sampai diperoleh adonan yang khalis. Hal in disebabkan kandungan protein tidak larut (gluten) sebagai pembentuk adonan hanya terdapat pada tepung terigu.

Sifat Fungsional Mi Kering dengan Substitusi Pati Sagu Termodifikasi HMT

\section{Waktu Optimum Rehidrasi Mi Kering} (Cooking Time)

Waktu optimum pemasakan (rehidrasi) adalah waktu yang dibutuhkan 
mi untuk kembali mengabsorpsi air sehingga teksturnya menjadi kenyal dan elastis seperti sebelum dikeringkan [21]. Proses rehidrasi mi kering dilakukan dengan merebus mi di dalam air mendidih hingga matang. Mi yang matang terlihat transparan dan tidak keras saat ditekan atau digigit. Jika waktu optimum rehidrasi dilewati maka tekstur mi akan mudah hancur [19]. Hasil pengukuran waktu optimum rehidrasi mi kering yang disubstitusi dengan pati sagu termodifikasi HMT dapat dilihat pada Gambar 4. Gambar 4 menunjukkan bahwa semakin besar substitusi pati sagu termodifikasi HMT, waktu yang dibutuhkan untuk mencapai tingkat masak optimum cenderung meningkat. Mi kering dengan tingkat substitusi pati sagu HMT 0 sampai 30\% membutuhkan waktu yang relatif sama untuk mencapai waktu optimum rehidrasi yaitu 4 menit. Perlakuan HMT 40 - 60\% membutuhkan waktu optimum rehidrasi 4,5 menit, selanjutnya mulai substitusi HMT $70 \%$ sampai penggunaan HMT 100\% waktu optimum rehidrasi terus meningkat. Perlakuan substitusi pati sagu alami 50\% membutuhkan waktu optimum rehidrasi yang lebih lama yaitu 5,5 menit, dibandingkan dengan substitusi pati sagu termodifikasi HMT 50\% yang membutuhkan waktu optimum rehidrasi 4,5 menit.

Hal ini berarti modifikasi pati secara HMT bisa memperpendek waktu optimum rehidrasi, oleh karena terjadinya peningkatan kandungan amilosa pada pati HMT. Dan ini sesuai dengan yang dinyatakan dalam [22] bahwa semakin besar kandungan amilosa, pati akan bersifat kering, kurang lekat dan mudah menyerap air. Dengan demikian air akan lebih mudah masuk ke struktur mi menyebabkan waktu optimum rehidrasi lebih cepat tercapai.

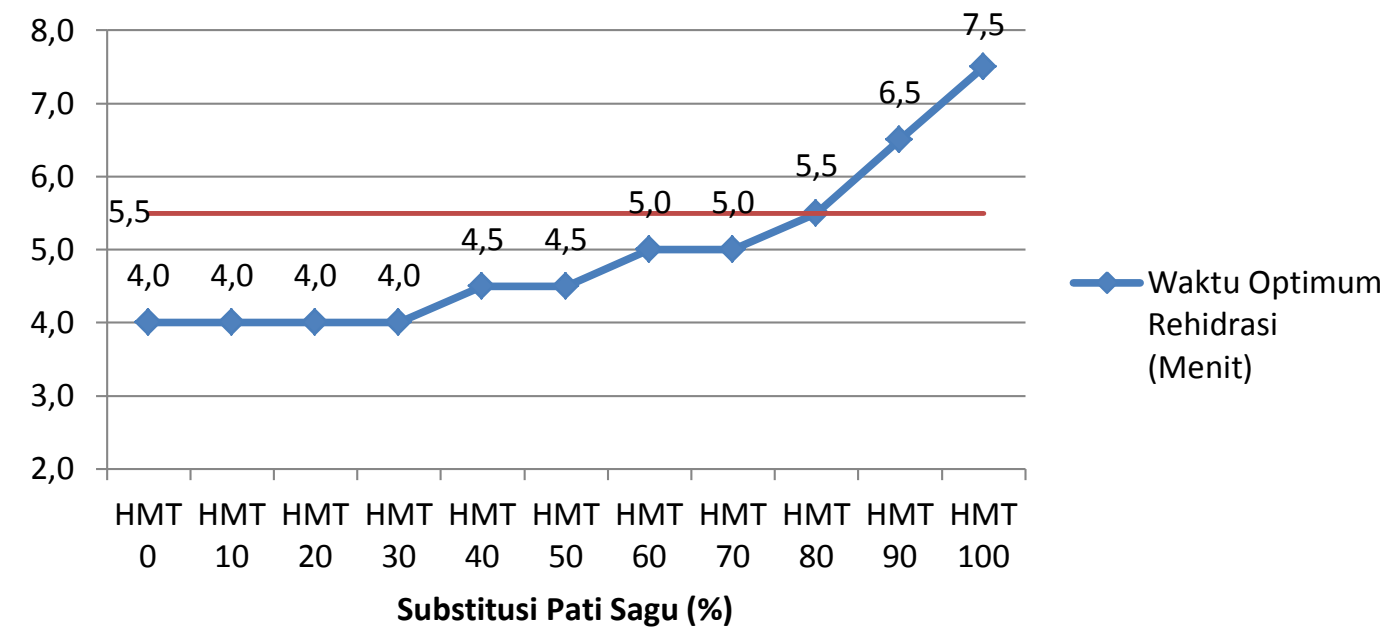

Gambar 4. Waktu Optimum Rehidrasi Mi Kering dengan Perlakuan Substitusi Pati Sagu.

Kehilangan Padatan Akibat

Pemasakan(Cooking Loss) Mi Kering

Pengukurancooking loss dilakukan untuk mengetahui jumlah padatan yang hilang akibat proses pemasakan. Mi kering yang diinginkan adalah mi kering dengan cooking loss yang minimum. Hasil pengukuran cooking loss dari mi kering 
dengan perlakuan substitusi pati sagu termodifikasi HMT dapat dilihat pada Gambar 5.

Gambar 5 menunjukkan bahwa semakin tinggi substitusi pati sagu termodifikasi HMT nilai cooking loss semakin kecil (\%). Hal ini berhubungan dengan kandungan amilosa dari pati sagu termodifikasi HMT yang mengalami peningkatan dari pati sagu alami, dan juga lebih tinggi dari kandungan amilosa pati gandum (tepung terigu). Kandungan rasio amilosa amilopektin pati gandum adalah (25:75), sedangkan pati sagu (27 : 73). Hasil pengujian fraksi amilosa dari pati sagu alami yang digunakan dalam penelitian ini adalah $20,0 \%$ dan mengalami peningkatan ketika sudah dimodifikasi secara HMT menjadi $25,5 \%$. Sedangkan fraksi amilosa tepung terigu (pati gandum) yang digunakan dalam penelitian ini tidak dianalisa.

Kandungan amilosa yang cukup tinggi merupakan suatu hal yang diharapkan dalam pembuatan mi kering karena memiliki daya ikat yang lebih kuat sehingga nilai cooking loss rendah [23].

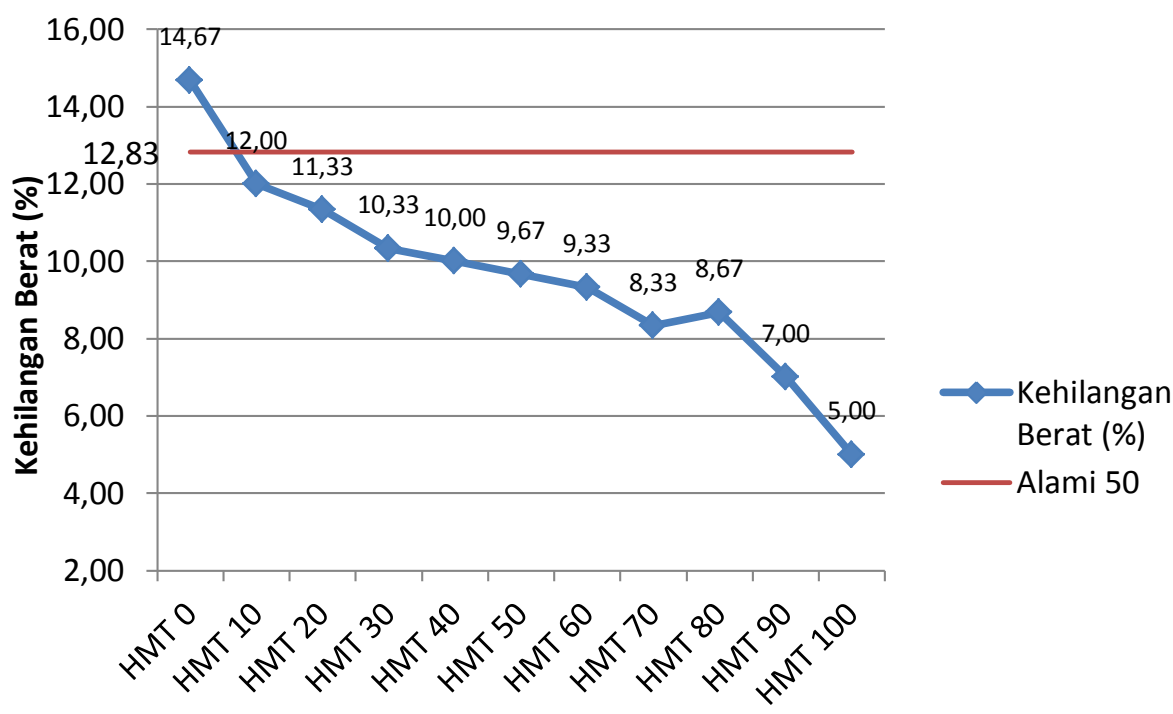

Substitusi Pati Sagu (\%)

Gambar 5. Cooking Loss Mi Kering dengan Perlakuan Substitusi Pati Sagu.

Kapasitas Pengembangan (Daya Serap Air) Mi Kering

Daya serap air merupakan kemampuan mi kering untuk menyerap air kembali setelah mengalami proses pengeringan dan akibat proses pemasakan.
Hal ini dapat diamati dari pengembangan ukuran $\mathrm{mi}$ setelah direhidrasi. Hasil pengukuran daya serap air dari mi kering dengan perlakuan substitusi pati sagu termodifikasi HMT dapat dilihat pada Gambar 6 beriku ini. 


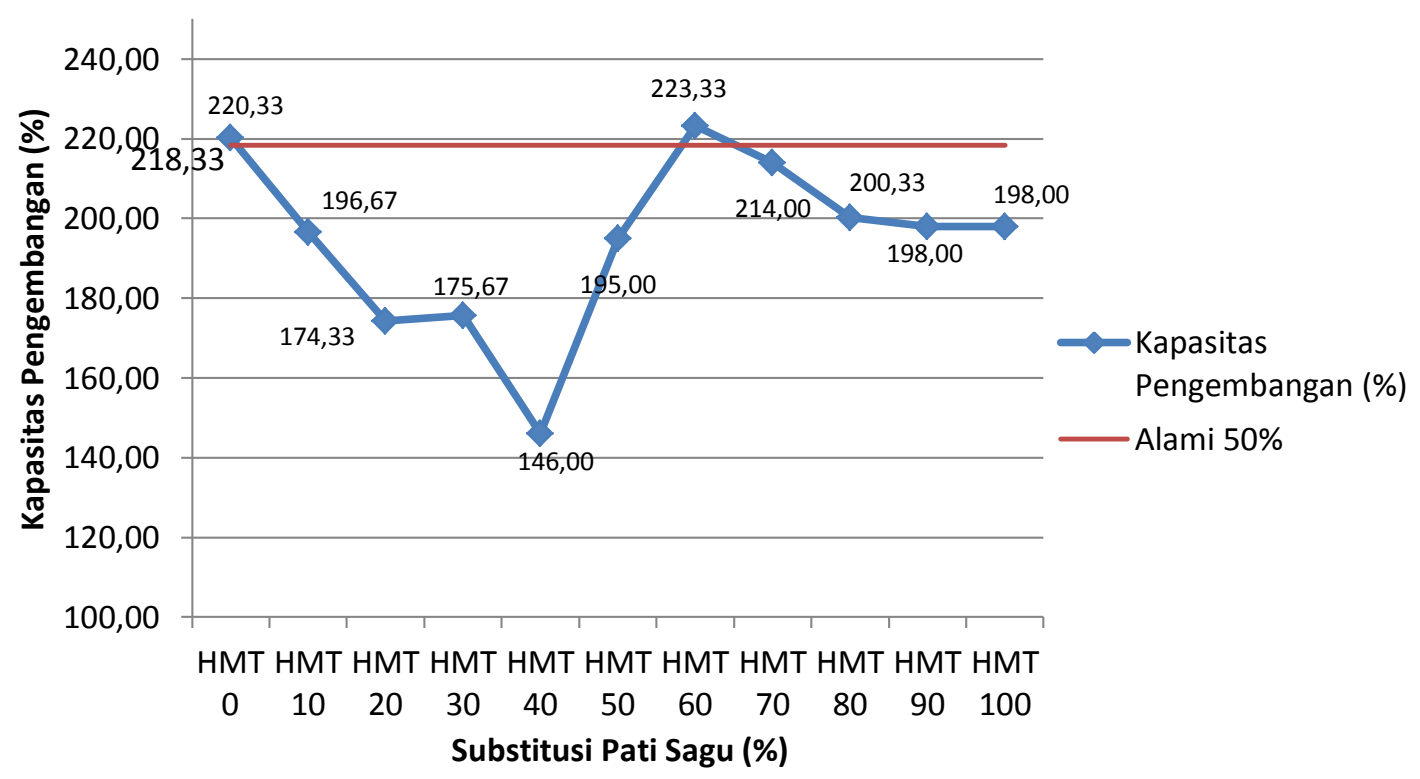

Gambar 6. Kapasitas Pengembangan Mi Kering dengan Perlakuan Substitusi Pati Sagu.

Gambar 6 menunjukkan bahwa kapasiatas pengemnbangan/daya serap air dari mi kering semakin kecil dengan makin meningkatnya substitusi pati sagu termodifikasi HMT. Hal ini berhubungan dengan kandungan amilosa dari kedua pati yang digunakan, dimana kandungan amilosa dari pati sagu termodifikasi HMT lebih tinggi dari kandungan amilosa pati gandum (tepung terigu). Semakin tinggi kadar amilosa semakin rendah daya pengembangan pati karena daya serap air semakin rendah. Kandungan amilosa yang tinggi menyebabkan pengembangan granula pati terjadi pada suhu yang lebih tinggi, akibatnya pati dengan kandungan amilosa yang lebih tinggi mempunyai daya pengembangan lebih rendah daripada pati dengan kandungan amilosa lebih rendah [24].Sedangkan dalam [8] dinyatakan bahwa aksi amilosa adalah sebagai penghambat (inhibitor) swelling (pembengkakan) pati.

\section{KESIMPULAN}

Karakteristik pati sagu baruk adalahmemiliki kadar air 7,48\%, kadar abu $0,062 \%$, serat kasar $0,04 \%$, kadar pati $88,31 \%$, fraksi amilosa $20 \%$, fraksi amilopektin $39,50 \%$ semuanya memenuhi syarat mutu tepung sagu SNI 3729:2008, dan mempunyai sifat fungsional yaitu swelling power4,35 (gr/gr) dan kelarutan $6,06 \%$.

Hasil modifikasi pati sagu secara HMT merubah sifat fungsional pati sagu yaitu meningkatkan kandungan fraksi amilosa menjadi $25,00 \%$, kelarutan pati sagu menjadi $17,2 \%$ dan sedikit menurunkan swelling power dari pati sagu menjadi 3,63 (gr/gr).

Pati sagu termodifikasi HMT dapat dimanfaatkan sebagai bahan substitusi tepung terigu dalam pembuatan mi kering, juga sebagai bahan baku baku pengganti tepung terigu.

Mi kering menggunakan $100 \%$ pati sagu termodifikasi HMT memiliki waktu 
optimum rehidrasi 7,5 menit yang relatif lebih lama dari waktu optimum rehidrasi mi kering pada umumnya yaitu sekitar 4 menit, juga memerlukan waktu yang lebih lama dalam pembentukan adonan untuk menghasilkan adonan yang cukup khalis dan tidak mudah patah.

Dibandingkan dengan SNI 8217:2015 Syarat Mutu Mi Kering (berbahan baku tepung terigu), mi kering yang dibuat dengan substitusi pati sagu termodifikasi HMT 30\% memenuhi syarat mutu untuk semua kriteria parameter yang diujikan dalam penelitian ini.

\section{DAFTAR PUSTAKA}

1. Novarianto $H$, Barat $P$. Sumber Daya Genetik Sagu Mendukung Pengembangan Sagu di Indonesia. Penguatan Inovasi Teknologi Mendukung Kemandirian Usahatani Perkebunan Rakyat. 2012. Hal 4-13.

2. Koswara S. Teknologi Modifikasi Pati. 2009. Available from: EbookPangan.com

3. Hee-Young An. Effects of Ozonation and Addition of Amino acids on Properties of Rice Starches. A Dissertation Submitted to the Graduate Faculty of the Louisiana state University and Agricultural and Mechanical College. 2005

4. Fitriani S, Sribudiani E. Rahmayuni. Karakteristik Mutu Pati Sagu Dari Provinsi Riau Dengan Perlakuan Heat Moisture Treatment (HMT). 2010. Hal 38-44.

5. Syamsir E, Hariyadi P. Fardiaz D. Pengaruh Proses Heat Moisture Treatment (HMT) Terhadap Karakteristik Fisikokimia Pati. Jurnal Teknologi dan Industri Pangan 2012 XXIII:1. Hal 100-106

6. Thahir R, Kusnandar F, Purwani E Y. Peningkatan Kualitas $\mathrm{Mi}$ Instan Sagu Melalui Modifikasi Heat Moisture Treatment. Dep IImu dan Teknologi Pangan Fakultas Teknologi Pertanian IPB Balai Besar Penelitian dan Pengembangan Pascapanen Pertanian. 2009. Hal 666667.

7. Albert $T W$, Ignatius $P$, Sindi $A$, Aning $S$. Modifikasi Asetilasi dan Cross-Linking. 2009. Hal 836-843.
8. Mohamed A, Jamilah B, Abbas K A, Abdul R R, Roselina K. A Review On Physicochemical And Thermorheological Properties Of Sago Starch. American Journal of Agricultural and Biological Science. 2008. Pages 639-646.

9. Polnaya F J. Kegunaan Pati Sagu Alami Dan Termodifikasi Serta Karakteristiknya. Jurnal Agroforestri 2006. I(3):50-56.

10. Ramadhan K. Aplikasi Pati Sagu Termodifikasi Heat Moisture Treatment Untuk Pembuatan Bihun Instan. Skripsi.Jurusan Teknologi Pertanian IPB. 2009.

11. Badan Standardisasi Nasional. SNI 3729:2008 Tepung Sagu. Jakarta.

12. Badan Standardisasi Nasional. SNI 8217:2015 Mi Kering. Jakarta.

13. Leach $H$ W, McCowen L D, Schoch $T J$. Structure Of The Starch Granule. I. Swelling And Solubility Patterns Of Various Starches. Cereal Chem. 36:534. 1959.

14. Falch M. Sago Palm. International Plant Genetic Resource Institute (IPGRI). Promoting the Conversation and Use Underutilized and Neglected Crops 13. IPGRI Italy adn IPK Germany.

15. Sugiyono, Thahir R, Kusnandar F, Purwani $E Y$, dan Herawati D. Peningkatan kualitas mi instan sagu melalui modifikasi heat moisture treatment. Prosiding Seminar Hasil-Hasil Penelitian IPB 2009.

16. Kusnandar F. Teknologi modifikasi pati dan aplikasinya di industri pangan. Dep. IImu Teknologi pangan IPB. 2010.

17. Bitin M M. Pengaruh Substitusi Tepung Sagu (Metroxylon Sagus Rottb.) Dan Penambahan Ekstrak Labu Kuning Terhadap Kualitas Mie Kering. Fakultas Teknobiologi Universitas Atma Jaya Yogyakarta. Skripsi. 2009.

18. Lay A, Indrawanto C, Status Dan Potensi Sagu Baruk Untuk Pangan Dan Konservasi Lahan. Perspektif Vol. 12 No. 2 Desember 2013. Hal 65-77.

19. Fitriani S. Karakteristik Fisikokimia Dan Organoleptik Mi Sagu Kering Berbahan Baku Pati Sagu Dari Propinsi Riau Dengan Perlakuan Heat Moisture Treatment (HMT). Fakultas Pertanian Universitas Riau. Lap. Penelitian. 2009.

20. Irawati. Modul Pengujian Mutu 1. Diploma IV PDPPTK Vedca. Cianjur. 2008.

21. Astawan M. Membuat Mi dan Bihun. Penebar Swadaya. Jakarta. 2006.

22. Wirakartakusumah M A. Kinetics of Starch Gelatinisation and Water Absorption in 
Rice. Ph.D Detertation. Univ. Of Wisconsin. Madison. 1984.

23. Kim S K. Instant Noodle. In Krueger J. Matsuo R. Dick J (Ed.). Paste Product: Chemistry and Technology. 195-225. American Association of Cereal Chemist. St. Paul Minn. 1996.

24. Jading A, Tethoo El, Payung P, Gultom S. Karakteristik Pati Sagu Hasil Pengeringan Secara Fluidisasi Menggunakan Slatpengering Cross Flow Fluiilized Bed Bertenaga Surya Dan Biomassa. Reaktor Vol. 13 No. 3. Juni 2011. Hal 115-1. 
